\title{
MANIFESTACIJSKA STUPNJEVITA TUŽBA I TUŽBA VJEROVNIKA PRIJE DOSPJELOSTI NJEGOVE TRAŽBINE
}

UDK: 347.(497.5)

DOI: $10.31141 / 2$ rpfs.2019.56.134.923

Pregledni rad

Primljeno: 1. IV. 2019.

\begin{abstract}
U radu se razmatraju pravne značajke manifestacijske stupnjevite tužbe te što se njima željelo postići. Posebno se analiziraju tužbeni zahtjevi koji se njima postavljaju i postupak koji se po njima provodi u dvije faze. Pri tome se ukazuje na određena važna pitanja koja se pojavljuju kod tretiranja imovinskopravnog interesa za podnošenje ovih tužbi, davanju pregleda imovine i obveza, a naročito podataka o utajenoj ili prikrivenoj imovini. Pledira se za ukidanje odredbi o prisegi i izjavi o točnosti danih podataka i navode se opravdani razlozi za takvu promjenu. Naglašava se da činidbe na koje je tuženik obvezan iz međusobnog odnosa stranaka ne treba ZPP ograničavati po vrstama, jer se time bezrazložno sužuju prava tužitelja kao vjerovnika. Navode se razlozi za preformuliranje odredbi čl. 186.b st. 2. i 3. ZPP-a o stupnjevitoj tužbi kao i druga zapažanja na koja zakonodavac nije reagirao u proteklih deset i više godina od kada su postojeće odredbe čl. 186b ZPP-a u primjeni, a nema naznaka da će se to dogoditi ni u skoroj budućnosti. Zbog toga ove tužbe teško postižu svoj cilj i svrhu kojoj su bile namijenjene. Nasuprot tome, tužba vjerovnika na ispunjenje tražbine prije njezine dospjelosti, koja je u naš parnični procesni sustav uvedena kao iznimka, može lako postati pravilo s obzirom na često ponašanje dužnika u kršenju ispunjenja preuzetih obveza u sadašnjim gospodarskim prilikama.
\end{abstract}

Ključne riječi: manifestacijska stupnjevita tužba, imovinskopravni intreres, tužba vjerovnika na ispunjenje tražbine prije dospjelosti

\section{UVOD}

Još je Novelom Zakona o parničnom postupku iz 2003. g. u hrvatsko parnično procesno pravo uvedena posebna vrsta kondamnetorne tužbe, tzv. stupnjevita tužba, po sličnom uzoru koji poznaje austrijsko parnično procesno pravo. Stupnjevita tužba predstavlja izuzetak od pravila: tužbeni zahtjev mora biti određen već u samoj tužbi prema odredbi čl. 186. st. 1. Zakona o parničnom postupku (NN53/91, 91/92,58/93, 112/99,88/01,117/03,88/05, 2/07, 84/08,123/08,57/11,148/11, 25713,89/14 - dalje

1 Dr. sc. Mladen Pavlović, znanstveni suradnik i sudac Suda časti pri HGK Zagreb, 21000 Split, Domovinskog rata 43, mladen.pavlovic 39@gmail.com 
ZPP). ${ }^{2}$ Pravozaštitni cilj ove tužbe ogleda se u mogućnosti tužitelja da utuži tražbinu čija visina, količina ili neki drugi njezin sadržaj tužitelju još nisu poznati, jer mu ih tuženik kojemu su ti podaci poznati ili dostupni odbija priopćiti ili mu pak uskraćuje uvid u njih.Tužbeni zahtjev stupnjevite tužbe slojevit je i ostvaruje se u dva stadija i to: 1) u vidu tzv. manifestacijskog zahtjeva za polaganje računa ili davanje pregleda određene imovine i 2) u vidu određenog zahtjeva za ispunjenje dugovane činidbe proistekle iz manifestacijskog zahtjeva. Prilikom podnošenja stupnjevite tužbe sudu, samo manifestacijski zahtjev treba biti određeno postavljen, dok će konačni i konkretni zahtjev tužitelj postaviti nakon što tijekom postupka tuženik položi račun ili nakon što tužitelj na drugi način prikupi potrebne podatake. ${ }^{3}$ Stupnjevita tužba trebala bi olakšati poziciju tužitelja u parnicama radi ostvarivanja prava iz međusobnih odnosa poslovodstva, ortakluka, poslovanja trgovačkih društava, skrbi nad imovinom, radnih odnosa, bračnih odnosa i drugih odnosa. ${ }^{4}$ Prvo, prema odredbi čl. 186. b st. 1. ZPP-a, tužitelj koji za to ima imovinskopravni interes može tužbom od suda zatražiti da naloži tuženiku koji je prema sadržaju međusobnog pravnog odnosa dužan položiti račun ili dati pregled neke imovine i obveza, odnosno tuženiku za kojeg je vjerojatno da nešto zna o utajenoj ili prikrivenoj imovini, da pod prisegom ili bez prisege položi račun ili potpuni pregled imovine i obveza, odnosno da priopći što mu je o utajenoj ili prikrivenoj imovini poznato te izjavi da su položeni račun, predani pregled imovine i obveza, odnosno da su dani podaci o utajenoj ili prikrivenoj imovini potpuni i točni.

Prema odredbi čl. 186.b st. 2. ZPP-a u sporovima u kojima tužitelj ne može postaviti tužbeni zahtjev za isplatu određenog iznosa novca, isporuku određene količine zamjenjivih stvari, predaju određenih stvari ili prijenos određenih prava prije nego što tuženik ispuni svoju obvezu polaganja računa ili predaje pregleda imovine i obveza, tužitelj može u tužbi istaknuti, pored manifestacijskog zahtjeva iz st. 1. ovog članka, i zahtjev u kojem će zatražiti od suda da tuženika osudi na isplatu određenog iznosa novca, isporuku ili predaju stvari ili prijenos prava, čiju će visinu, količinu odnosno istovjetnost odrediti tek nakon što tuženik položi račun ili preda pregled imovine i obveza, odnosno tek nakon što se provede vještačenje

2 Prema odredbi čl. 186. st. 1. ZPP-a, tužba treba sadržavati određeni zahtjev u pogledu glavne stvari i sporednih traženja, činjenice na kojima tužitelj temelji tužbeni zahtjev, dokaze kojima se utvrđuju te činjenice i druge podatke koje mora imati svaki podnesak prema odredbama čl. 106. ZPP-a, a upravo prema tim odredbama: tužba, odgovor na tužbu, pravni lijekovi i druge izjave, prijedlozi i saopćenja koji se daju izvan rasprave podnose se u pisanom obliku (pisani podnesci). Podnesci moraju biti razumljivi i moraju sadržavati sve ono što je potrebno da bi se po njima moglo postupiti. Oni osobito moraju sadržavati: oznaku suda, ime, prebivalište, odnosno boravište stranaka, njihovih zakonskih zastupnika i punomoćnika ako ih imaju, osobni identifikacijski broj stranke koja podnosi podesak, predmet spora, sadržaj izjave i potpis podnositelja. Stranka, odnosno njezin zastupnik potpisuju podnesak na njegovu kraju. Ako izjava sadrži kakav zahtjev, stranka u podnesku mora navesti činjenice na kojima temelji taj zahtjev i dokaze kad je to potrebno. Izjava koja se daje podneskom može se umjesto podneskom dati usmeno na zapisnik kod parničnog suda.

Mihajlo Dika, Samostalna manifestacijska tužba i stupnjevita tužba, PuG, Zagreb, br.1/2005, str. 5-26 (dalje: Dika).

4 Miroslav Šumanović, Tužbe u parničnom postupku, Novote u parničnom postupku, Organizator, Zagreb, 2003., str. 181. 
ili izvedu drugi dokazi u povodu položenog računa ili predanog pregleda imovne i obveza ili u povodu uskrate polaganja računa ili predaje pregleda imovine i obveza.

Prema odredbi čl. 186. st. 3. ZPP-a, u sporovima u kojima tužitelj ne može postaviti određeni zahtjev prije nego što dođe do podataka koje mu tuženik ne želi dati, premda njima raspolaže, a koje mu je prema sadržaju građanskopravnog odnosa dužan dati, odnosno koji se mogu smatrati zajedničkima za obje stranke, tužitelj može u tužbi istaknuti zahtjev kojim će zatražiti od suda da tuženika osudi na isplatu iznosa, predaju stvari ili prijenos prava čiju će visinu, količinu, odnosno istovjetnost odrediti tek nakon što mu tuženik dade potrebne podatke, odnosno tek nakon što se provede vještačenje ili izvedu drugi dokazi o podacima koje tuženik izbjegava dati. Prema odredbi čl. 186. st. 4. ZPP-a, u slučajevima navedenima u odredbi st. 3. ovog članka, tužitelj je dužan određeni zahtjev postaviti u roku koji mu sud odredi tijekom postupka svojim rješenjem protiv kojeg nije dopuštena posebna žalba. Prema odredbama čl. 186. st. 5. i 40. ZPP-a, u stupnjevitoj tužbi po manifestacijskom zahtjevu tužitelj je dužan naznačiti vrijednost predmeta spora kao u slučaju kad se tužbeni zahtjev ne odnosi na novčanu svotu. Prilikom konačnog i određenog postavljanja drugog tužbenog zahtejva, tužitelj je dužan iznova naznačiti vrijednost predmeta spora u skladu s mjerodavnim odredbama čl. 35 - 37 ZPP-a. ${ }^{5}$

Prema odredbama čl. 186c ZPP-a, tužitelj koji učini vjerojatnim da tuženik ozbiljno dovodi u pitanje postojanje njegove još uvijek nedospjele tražbine ili da će morati sudskim putem ostvarivati takvu svoju tražbinu nakon što ona dospije ili iz drugih razloga za to ima pravni interes, može i prije dospjelosti takve tražbine zatražiti od suda da tuženiku naloži ispuniti dužnu činidbu u vrijeme njezine dospjelosti. Takva tražbina i vrijeme njezine dospjelosti trebaju biti određeno naznačeni u tužbenom zahtjevu. Sud će odbaciti tužbu ako utvrdi da tužitelj nema pravnog interesa tražiti donošenje presude prije dospjelosti tražbine. Ovrha na temelju ovakve presude kojom je prihvaćen zahtjev tužitelja može se tražiti tek nakon dospjelosti tražbine koja je njome dosuđena. ${ }^{6}$

Uvođenje navedenih tužbi u naš procesni parnični sustav trebalo je poslužiti ostvarivanju glavnih ciljeva, a to su učinkovitost i koncetracija postupanja u ostvarivanju pravne zaštite po njima. Je li se, s obzirom na složenost i slojevitost odredbi ZPP-a koje su uvodno navedene, a koje omogućavaju takvu pravnu zaštitu, kroz višegodišnje razdoblje njihove primjene u tome uspjelo, prepušta se ocjena javnosti. ${ }^{7} \mathrm{U}$ ovom prikazu nastojat ćemo ukazati na pravne osobitosti manifestacijske i stupnjevite tužbe te tužbe vjerovnika koji ima pravni interes za donošenjem kondamnetorne presude prije dospjelosti njegove tražbine te neka zapažanja u pogledu realizacije ovih procesnih pravnih instituta.

5 Siniša Triva i Mihajlo Dika, Građansko parnično procesno pravo, NN, Zagreb 2004., str., 406-407 (dalje: Triva-Dika).

6 Ivo Grbin, "Nove vrste tužbi i odluka u parničnom postupku". PuG br.6/2005, str. 275-311 (dalje: Grbin).

7 Svakako bi bilo zanimljivo vidjeti kroz sudsku praksu koliko je ovih tužbi bilo u zadnjih deset godina. 


\section{UVOĐENJE MANIFESTACIJSKE TUŽBE U NAŠ PARNIČNI PROCESNI SUSTAV}

Manifestacijska tužba preuzeta je u naš parnični procesni sustav iz austrijskog prava $\mathrm{s}$ velikim zakašnjenjenjem od preko 100 godina. ${ }^{8}$ Stječe se dojam da je prilikom preuzimanja tako starog propisa trebalo istog prethodno podvrći određenoj kritici kako bi ga se uskladilo s potrebama današnjih prilika. Međutim, tako nije postupljeno, nego je pruzet kompletni sadržaj čl. XLII. Uvodnog zakona ZPO-a (dalje EGZPO) i još su dodane odredbe koje manifestacijsku i stupnjevitu tužbu u njihovoj primjeni čine dodatno nejasnom. Naši eminentni autori građanskog parničnog procesnog prava Mihajlo Dika i Ivo Grbin u svojim radovima, koji su navedeni u bilješkama pod 2) i 5) ovoga napisa, još su prije više od deset godina upozoravali da ovako procesno koncipirane nove tužbe neće polučiti očekivane rezultate, što se u praksi pokazalo točnim, ali do danas odredbe o njima u ZPP-u nisu se izmijenile. ${ }^{9}$

\subsection{Imovinskopravni interes za podnošenje manifestacijske tužbe}

Kako bi tužitelj mogao ostvariti pravnu zaštitu pred sudom, koju tužbom traži, mora imati pravni interes. Pravni je interes pozitivna procesna pretpostavka pa njegov nedostatak dovodi do odbacivanja tužbe prema odredbi čl. 288. st. 2. ZPPa. ${ }^{10}$ Postojanje pravnog interesa zahtijeva se u pravilu kod traženja deklaratorne pravne zaštite. ${ }^{11}$ Međutim, u nekim je slučajevima dokazivanje njegova postojanja potrebno i kod podnošenja kondamnetorne tužbe, kod koje se u načelu pretpostavlja njegovo postojanje. ${ }^{12}$ Prema odredbi čl. 186b st. 1 . ZPP-a, tužitelj mora imati imovinskopravni interes za podnošenje manifestacijske tužbe. Kod nas se mogu postavljati manifestacijski tužbeni zahtjevi kod kojih je taj imovinskopravni interes tužitelja javnopravni, ali ne i privatnopravni interes koji nije imovinskopravnog obilježja. Zato bi, uslijed pomanjkanja takvog imovinskopravnog interesa, tužbu

Kao uzor odredbama čl. 186 b) ZPP-a, poslužio je čl. XLII. austrijskog Uvodnog zakona za ZPO iz 1985. g.

9 Nisu nikakve promjene predviđene ni Nacrtom Prijedloga ZIDZPP od 19. svibnja 2016. koji je još u razmatranju.

10 Prema odredbi čl. 288. st. 2. ZPP-a, osim rješenja koja je ovlašten donositi nakon prethodnog ispitivanja tužbe na pripremnom ročištu, sud donosi i rješenje o odbacivanju tužbe ako utvrdi da o tužbenom zahtjevu već teče parnica, da je stvar pravomoćno presuđena, da je o predmetu spora sklopljena sudska nagodba, da se tužitelj u prijašnjoj parnici odrekao tužbenog zahtjeva ili da ne postoji pravni interes tužitelja za podnošenje tužbe za utvrđenje.

11 Tužba za utvrđenje može se podnijeti kada je to posebnim propisima predviđeno, kad tužitelj ima pravni interes da sud utvrdi postojanje ili nepostojanje kakva prava ili pravnog odnosa ili istinitost odnosno neistinitost kakve isprave prije dospjelosti zahtjeva za činidbu iz istog odnosa ili kad tužitelj ima kakav drugi pravni interes za podizanje takve tužbe.

12 U smislu čl. XLII. st. 2. EGZPO-a, podnositelj manifestacijske tužbe može ostvariti pravnu zaštitu ako za nju ima privatnopravni interes. Razlog za takvu odredbu jest onemogućivanje putem manifestacijske tužbe ostvarivanja nekih fiskalnih ili poreznih zahtjeva. Ako privatnopravni interes ne postoji, tužbu valja odbaciti. V. Grbin, str. 285. 
tužitelja valjalo odbaciti. ${ }^{13}$ Pravilno ukazuje Grbin da je odredba o pravnom interesu (imovinskopravnog karaktera) u manifestacijskoj tužbi s jedne strane nepotrebno unesena, a s druge strane da je ipak korisna jer u nekim slučajevima, kada se zahtijeva od tuženika polaganje računa, odnosno davanje pregleda neke imovine i obveza, tužitelj neće uspjeti u tužbi ako tuženik već od prije nije u obvezi udovoljiti takvom tužbenom zahtjevu. Takav bi kondamnetorni zahtjev tužitelj mogao ostvariti u parnici i kada ne bi uopće postojale zakonske odredbe o manifesatcijskoj tužbi i pri tome se od njega ne bi zahtijevalo dokazivanje postojanja bilo kakvog pravnog interesa. Stoga je neumjesno i kontraproduktivno ispitivati u takvim slučajevima ima li tužitelj i privatnopravni interes. Ako bi se to ipak učinilo manifestacijskom tužbom, koja služi zaštiti tužiteljevih interesa, njegov pravni polažaj samo bi se još pogoršao. To su davno uočili i austrijski pravnici koji smatraju da u navedenim slučajevima kod podnošenja manifestacijske tužbe ne dolazi u obzir ni ispitivanje pravnog interesa. Takvo motrište treba prihvatiti i u hrvatskom građanskom parničnom procesnom pravu. Protivno tome postoji zastrašujuća mogućnost da tužitelj poput nekog policijskog isljednika putem parničnog postupka traži podatke o utajenoj ili prikrivenoj imovini od onih koji mu ih nisu dužni dati. Zato takvu mogućnost treba svesti na najmanju moguću mjeru, čemu služi i odredba o postojanju imovinskopravnog interesa. ${ }^{14}$

\subsection{Sadržaj manifestacijske tužbe}

Kako bi pravni subjekti ponekad mogli utvrditi imaju li neko pravo te kakav je njegov sadržaj, potrebni su im podaci koji im nisu dostupni jer tim podacima raspolažu neke druge osobe. Pri tome ne postoji neko opće pravilo koje propisuje kako su te osobe dužne dostupnima učiniti te podatke svakom zainteresiranom subjektu te da im se sudskom odlukom može naložiti takvo postupanje. Ta dužnost postoji samo kao iznimka koja je uspostavljena manifestacijskom tužbom. ${ }^{15}$ Manifestacijska je tužba kondamnetorna tužba kojom se u smislu odredbe čl. 186.b st. 1. ZPP-a zahtjeva da se tuženiku naloži ispunjenje jedne od sljedećih činidbi: a) polaganje računa, b) davanje pregleda neke imovine i obveza i c) priopćavanje podataka o utajenoj ili prikrivenoj imovini. ${ }^{16}$ U slučajevima pod a) i b) nije tužitelju

13 Naziv imovinsko pravo neposredno asocira na sadržaj toga prava i prirodu odnosa koje uređuje, pa se može kazati da je isti određen "ratione materiae".To mu je svakako značajna predsnost pred ostalim nazivima. Nazivu se prigovara da je s jedne strane preširok, jer su imovnska prava također $\mathrm{i}$ trgovačko, financijsko i neka druga prava, a s druge strane da je preuzak jer ne obuhvaća zaštitu čovjekove neimovinske sfere. Ovaj drugi prigovor ne može se prihvatiti jer imovinsko pravo uređuje uglavnom imovinsku zaštitu iz čovjekove neimovinske sfere, dok prvi prigovor stoji, što je jedan od značajnijih razloga zbog kojeg je umjesto naziva "imovinsko pravo" prihvaćen naziv "građansko pravo". V. Martin Vedriš i Petar Klarić, Građansko pravo, NN, Zagreb 2004., str. 6-7 (dalje: Vedriš-Klarić).

14 V. Grbin, str. 286. i Dika, str. 13.

15 V. Dika, str. 5. i Šumanović, str. 182.

16 Ukoliko su ispunjene pretpostavke iz odredbi čl. 188. ZPP-a, takvi bi se zahtjevi mogli i kumulirati. V. više: Jozo Čizmić, Preinaka tužbe, Zbornik Pravnog fakulteta Sveučilišta u Rijeci (1991.) v. 28. br. $1 / 2007$. 
donesenom Novelom ZPP-a iz 2003. g. priznato neko novo samostalno pravo na podnošenje manifestacijske tužbe koje on do tada nije imao. Tužitelj može s uspjehom zahtijevati od tuženika polaganje računa odnosno davanje pregleda neke imovine i obveza samo u slučaju da među njima već postoji pravni odnos iz kojega slijedi dužnost tuženika na ispunjenje navedenih činidbi. Zbog toga tužitelj nije ovlašten zahtijevati polaganje računa, odnosno davanje pregleda neke imovine i obveza, ako tuženik nije već otprije u obvezi to učiniti. Postojanje te obveze proizlazi iz sadržaja međusobnog pravnog odnosa na osnovi kojega se podnosi tužba kojom se traži polaganje računa i/ili davanje pregleda imovine i obveza. Dužnost polaganja računa ili davanja pregleda neke imovine i obveza može se temeljiti na nekom pozitivnom propisu ili ugovoru. Treba naglasiti da građansko pravo ne sadrži opće i jedinstvene propise o tome koje pretpostavke trebaju biti ispunjene da bi se realizirala takva dužnost, već je to uređenje pripušteno različitim propisima. Zbog toga postojanje takve dužnosti valja procjenjivati u svakom konkretnom slučaju posebno. Zakonska dužnost davanja određenih obavijesti i podataka može se odnositi i na neki ugovorni odnos. Međutim, postoji mogućnost da same stranke ustanove takvu dužnost ugovorom i onda kada ona ne proizlazi iz odredbi nekog pozitivnog propisa. Dakle, takva dužnost može biti izričito ugovorena, a može proizlaziti iz adekvatnog tumačenja međusobnog ugovornog odnosa. ${ }^{17}$ Postavlja se opravdano pitanje može li tuženik od tužitelja u postupku po manifestacijskoj tužbi uputiti prigovore kojima će na isti način od tužitelja tražiti polaganje računa ili davanja pregleda neke imovine i obveza zbog nedostatka njemu nužnih podataka, na koje valja odgovoriti da to tuženik ne može učiniti prigovorom, nego samo podnošenjem eventualno manifestacijske protutužbe pod pretpostavkama iz odredbi čl. 189. ZPPa. ${ }^{18} \mathrm{U}$ slučaju pod c) traženja priopćenja podataka o utajenoj ili prikrivenoj imovini izravna je tuženikova obveza koja neposredno proizlazi iz odredbe čl. 186.b st. 1. ZPP-a, pa u tom slučaju nema upućivanja na odredbe materijalnog građanskog prava o međusobnom pravnom odnosu stranaka kao u slučajevima pod a) i b), niti se tužiteljev tužbeni zahtjev temelji na tim odredbama. ${ }^{19}$ Kako se zahtjevi iz manifestacijske tužbe ne odnose na novčane tražbine, to znači da je tužitelj dužan

17 V. Mladen Pavlović, "Tumačenje ugovora", Pravo u gospodarstvu, Zagreb, br. 5/2007, str. 3-21.

18 Prema odredbama čl. 189. ZPP-a, tuženik može do zaključenja prethodnog postupka pred sudom podnijeti kod istog suda protutužbu, ako je zahtjev protutužbe u svezi s tužbenim zahtjevom ili ako se ti zahtjevi mogu prebiti ili ako se protutužbom traži utvrđenje kakva prava ili pravnog odnosa o čijem postojanju ili nepostojanju ovisi u cijelosti ili djelomično odluka o tužbenom zahtjevu. Protutužba se ne može podnijeti ako je za zahtjev iz protutužbe stvarno nadležan viši sud ili sud druge vrste. Protutužba se može podnijeti i kad o zahtjevu iz protutužbe treba suditi isti sud u drugom sastavu.

19 V. Grbin, str. 278. 
Dr. sc. Mladen Pavlović: Manifestacijska stupnjevita tužba i tužba vjerovnika prije dospjelosti njegove... Zbornik radova Pravnog fakulteta u Splitu, god. 56, 4/2019, str. 923-944

već u tužbi naznačiti vrijednost predmeta spora u skladu s odredbama čl. 40. st. 2. u svezi s čl. 186.b st. 5. ZPP-a. ${ }^{20}$

\subsection{Polaganje računa te davanje pregleda imovine i obveza}

Ne postoji ni neki opći pojam o polaganju računa. Pri utvrđivanju njegova sadržaja valja poći od toga da on čini sporedni zahtjev ovlaštenika, koji mu treba omogućiti zadovoljavajuću kontrolu obveznika i priskrbiti mu podatke radi postavljanja eventualnih daljnih zahtjeva prema njemu. U svakom konkretnom slučaju, ovisno o okolnostima za određivanje sadržaja i opsega polaganja računa mjerodavna je njegova svrha. Zato on treba biti detaljiziran, a ne samo prikaz konačnih brojki. Ne može se smatrati da je obveznik ispunio svoju obvezu polaganja računa ako je ovlašteniku samo predao dokumentaciju, nego treba obrazložiti sve stavke računa uz prilaganje odgovarajućih isprava. Naš je zakonodavac u odredbi čl. 186.b st. 1.ZPP-a izričito propisao da i polaganje računa može biti predmetom manifestacijske tužbe. Kod nas su na snazi mnogi propisi koji nalažu nekoj od stranaka da protivnoj stranci polože račun. Takve odredbe nalazimo najviše u Zakonu o obveznim odnosima (NN 35/05,41/08,125/11,78/15,29/18 - dalje ZOO) na području reguliranja ugovornih i izvanugovornih odnosa. ${ }^{21}$ Zakon o vlasništvu i drugim stvarnim pravima (NN 91/96,68/98,137/99,22/00,73700, 129/00,114/01,79/06,141/06,146703,38709,153 /09, 143/12, 152/14 - dalje ZoV) također sadrži odredbe o polaganju računa. One se odnose na suvlasnike iz čl. 38 . ZoV-a te na zajedničkog upravitelja nekretnine kada postoji vlasništvo posebnih dijelova nekretnine iz čl. 90. i 93. ZoV-a. I prema

20 Prema odredbama čl. 40. st. 2.-5. ZPP-a, u drugim slučajevima, kada se tužbeni zahtjev ne odnosi na novčanu svotu, mjerodavna je vrijednost predmeta spora koju je tužitelj naznačio u tužbi. Ako je u slučaju iz st. 2. ovog članka tužitelj vrijednost predmeta spora očito suviše visoko ili nisko naznačio, tako da se postvalja pitanje stvarne nadležnosti, sastava suda, vrste postupka, prava na izjavljivanje revizije, ovlaštenja na zastupanje ili prava na naknadu troškova postupka, sud će po službenoj dužnosti ili po prigovoru tuženika najkasnije na pripremnom ročištu hitro i na prikladan način provjeriti točnost naznačene vrijednosti te rješenjem protiv kojeg nije dopuštena posebna žalba odrediti vrijednost predmeta spora. Ako se utvrdi nakon upuštanja tuženika u raspravljanje o glavnoj stvari, da je tužitelj propustio odrediti vrijednost predmeta spora, sud prvog stupnja će brzo i na prikladan način, nakon što strankama omogući izjasniti se o tome, odrediti vrijednost predmeta spora rješenjem protiv kojeg nije dopuštena posebna žalba. Ako prvostupanjski sud u slučaju iz st. 4. ovog članka ne utvrdi vrijednost predmeta spora do zaključenja glavne rasprave, smatrat će se da je vrijednost predmeta spora $50.000,00 \mathrm{kn}$.

${ }_{21}$ Tako, primjerice, prema odredbi čl. 647h st. 1. ZOO-a, ortaci kojima je povjereno poslovodstvo u ortakluku dužni su uredno voditi poslovne knjige i polagati račun o stanju zajedničke imovine te svim prihodima i rashodima. Prema odredbi čl. 768. ZOO-a o obvaljenom poslu, nalogoprimac je dužan položiti račun i predati bez odugovlačenja nalogodavcu sve što je primio na temelju obavljanja povjerenih mu poslova, bez obzira na to je li ono što je primio za nalogodavca bilo dugovano ovome ili nije, prema čl. 769. ZOO-a, nalogoprimac je dužan na zahtjev nalogodavca podnijeti izvješće o stanju poslova i položiti račun i prije određenog vremena. Prema odrebi čl. 794. st. 1. ZOO-a, komisionar je dužan položiti račun o obavljenom poslu bez nepotrebnog odugovlačenja. Prema odredbama čl. 860. ZOO-a, otpremnik je dužan nakon završenog posla položiti račun nalogodavcu, a prema zahtjevu nalogodavca otpremnik je dužan položiti račun i u tijeku izvršavanja usluga. Kod izvanugovornih odnosa ta obveza postoji kod poslovođe bez naloga. Tako, primjerice, odredbama čl. 1122. st. 1-3. ZOO-a, poslovođa je dužan što je moguće prije obavijestiti gospodara posla i nastaviti započeti posao, ako mu je to razumno moguće, dok ovaj ne bude mogao preuzeti brigu o njemu. Nakon završenog posla on je dužan položiti račun i ustupiti gospodaru posla sve što je pribavio obvaljajući njegov posao i ima obveze nalogoprimca. 
Zakonu o radu (NN93/14,127/17), koji je na snazi od 28. prosinca 2017. godine, prema odredbama čl. 93., prilikom isplate plaće, naknade plaće i otpremnine, poslodovac je dužan radniku uručiti obračun (položiti račun) iz kojeg je razvidno kako su i na osnovi čega ove naknade utvrđene. ${ }^{22} \mathrm{U}$ odredbi članka 186.b st. 1. ZPP-a nije pobliže pojašnjeno ni što se smatra pod pojmom predaje pregleda neke imovine i obveza, pa odgovor i na to pitanje treba potražiti u odredbama građanskog prava. Tako se npr. u austrijskoj pravnoj literaturi imovinom smatra sva ona aktiva koja može biti predmet tužbe na činidbu, dok se u hrvatskoj doktrini imovina tretira kao gospodarska, pravna i knjigovodstvena kategorija. ${ }^{23} \mathrm{Tu}$ spadaju pokretnine, nekretnine i tražbine (novčane i nenovčane). Pri traženju podataka ne mora se raditi o cjelokupnoj nečijoj imovini, nego o pojedinim njezinim dijelovima (predmetima) koji joj pripadaju. Ti predmeti ne moraju čak imati neku prometnu vrijednost. U navedenoj odredbi ZPP-a nije ni u pogledu obveza drukčija situacija, pa opet i kod njih treba konzultirati odredbe građanskog prava. Opravdano se možemo zapitati o kakvim se tu obvezama radi? Kada je riječ o obvezama tuženika prema tužielju, tada bi ova odredba ZPP-a o davanju pregleda obveza trebala biti suvišna, jer je tuženikova obveza u tom slučaju ujedno i tužiteljeva tražbina kao dio njegove imovine. Stoga posebna odredba o davanju pregleda obveza ima smisla samo kada tužitelj zahtijeva podatke o svojim vlastitim obvezama prema trećima, jer one ne spadaju u njegovu imovinu, nego u stvari predstavljaju njezin teret. ${ }^{24}$

\subsection{Davanje podataka o utajenoj ili prikrivenoj imovini}

Već je spomenuto da zahtjev za davanje podataka o utajenoj ili prikrivenoj imovini proizlazi neposredno iz same odredbe čl. 186.b st. 1. ZPP-a te na taj način jedna procesna odredba osigurava samostalno materijlano pravo tužitelja na traženje određenih obavijesti. U svezi s traženjem tih obavijesti Grbin navodi da se u Austriji javljaju brojni problemi jer austrijski propisi ništa pobliže ne navode o davanju tih podataka. Tako na pitanje o čijoj se tu utajenoj ili prikrivenoj imovini radi, austijska doktrina odgovara da to treba biti tužiteljeva imovina. Za prihvatiti je stajalište Grbina kako takvo motrište nije prihvatljivo za hrvatsko pravo jer to ne proizlazi iz odredbe čl. 186.b st. 1. ZPP-a koja ne navodi titulara te imovine. Pored toga, netko treći, primjerice titularov vjerovnik, može i te kako biti zainteresiran za tužiteljevu imovinu, pa bi i njemu trebalo omogućiti da dođe do podataka o njoj. Također se ukazuje prijepornim je li u parnici povodom manifestacijske tužbe pasivno

22 V. Grbin, str. 279.

23 Tako se imovina u gospodarskom smislu definira kao skup dobara koja pripadaju određenom subjektu, dok je imovina u pravnom smislu skup subjektivnih imovinskih prava predstavljenih jednim subjektom. V. Vedriš-Klarić, str. 93 i 94. i Mladen Pavlović, "Tretiranje imovine u hrvatskom građanskom pravu", PuG, Zagreb, br. 2/2017, str. 321-326.

24 U svezi s pravnim pojmom imovine postavlja se još jedno interesantno pitanje, a to je što je s obvezama? Zar obveze nisu dio imovine? Po suvremenom shvaćanju, obveze nisu samostalan dio imovine, nego su one teret imovine, zapravo teret na pojedinim subjektivnim građanskim pravima. To istodobno znači da ima obveza koje uopće niti kao teret ne ulaze u imovinu. V. Vedriš-Klarić, str. 95. i Grbin, str. 280. 
legitimiran samo onaj tko je sudjelovao u utajenju ili prikrivanju imovine. Na to pitanje kod nas treba dati niječni odgovor te omogućiti zainteresiranom tužitelju koji ima imovinskopravni interes da dobije podatke o utajenoj ili prikrivenoj imovini od svakoga tko o toj imovini nešto zna, neovisno o tome je li imao kakvu ulogu u njezinu utajenju ili prikrivanju.

Kako bi netko manifestacijskom tužbom mogao tražiti podatke o nekoj imovini, uvjet je da on tim podacima u cijelosti ne raspolaže, ali je pitanje koje od njemu nepoznatih podataka tužitelj može tražiti od tuženika? U svakom slučaju, moraju mu se na raspolaganje staviti podaci o vrsti i opsegu imovine, a u austrijskoj sudskoj praksi i doktrini sporno je mogu li se manifestacijskom tužbom tražiti podaci o tome gdje se nalazi neka imovina; njezina vrsta i opseg tuženiku su, doduše, poznati, ali on ne zna gdje je ta imovina smještena. Za prihvatiti je također motrište Grbina da odredba čl. 186.b st. 1. ZPP-a ne sprečava tužbom traženje podataka o tome gdje se ta imovina nalazi. S druge strane, manifestacijska tužba može se s osnovom podnijeti samo protiv onoga tko raspolaže podacima o mjerodavnim okolnostima utajivanja ili prikrivanja imovine. U svezi s time se postavlja još jedno zaista važno pitanje mjere u kojoj tužitelj mora dokazivati tuženikovo znanje o utajenoj ili prikrivenoj imovini. Bilo bi neopravdano omogućiti tužitelju da vodi sudski postupak protiv svakoga za koga smatra da možda nešto zna o toj imovini, ali bi isto tako bilo neopravdano zahtijevati od tužitelja da dokaže tuženikovo znanje o navedenim mjerodavnim okolnostima, jer bi tada tuženikovo izjašnjenje bilo suvišno. Zato odredba čl. 186.b st. 1. ZPP-a propisuje da se za davanje podataka o utajenoj ili prikrivenoj imovini može obvezati samo onaj za koga je vjerojatno da nešto zna o tome, čime je prihvaćeno srednje rješenje. Zadatak sudske prakse i pravne doktrine jest riješiti još jedan problem koji je zakonodavac ostavio otvorenim, a odnosi se na to može li se tuženika prisiljavati da uvijek i neograničeno puta daje podatke o nekoj utajenoj ili prikrivenoj imovini. Tako, primjerice, procesni propisi ponekad zabranjuju svjedočenje ${ }^{25}$ te daju svjedoku pravo da uskrati svjedočenje ili odgovor na pojedina pitanja, dok se tuženika uopće ne može siliti da dade stranački iskaz, pa se nužno nameće potreba uporedbe pravnog položaja između svjedoka i tuženika od kojeg se traže podaci o utajenoj ili prikrivenoj imovini. Prilikom reguliranja manifestacijske tužbe zakonodavac ne upućuje na odredbe o svjedočenju. ${ }^{26}$ Zato je i ovdje za prihvatiti motrište Grbina, da manifestacijska tužba radi pribavljanja podataka o utajenoj ili prikrivenoj imovini jedva spada u područje građanskog

25 Prema odredbi čl. 236. ZPP-a, ne može se saslušati kao svjedok osoba koja bi svojim iskazom povrijedila dužnost čuvanja službene ili vojne tajne, dok je nadležno tijelo ne oslobodi te dužnosti. Prema odredbi čl. 240. st. 1. ZPP-a, opravdanost razloga za uskraćivanje svjedočenja ili odgovora na pojedina pitanja ocjenjuje sud pred kojim svjedok treba svjedočiti. Ako je potrebno, prije toga će se o tome saslušati stranka.

26 Za razliku od austrijske literature koja, iako ne u jednakoj mjeri kao kod svjedočenja, priznaje tuženiku pravo, ali i dužnost uskraćivanja davanja podataka o utajenoj ili prikrivenoj imovini, u hrvatskoj se pravnoj doktrini postojanje tog tuženikova prava negira. V. Grbin, str. 280-282 i tamo navedene bilješke. 
parničnog procesnog prava te da je treba restriktivno primjenjivati. ${ }^{27}$ Tužitelj je ipak na temelju odredbe čl. 186.b st. 1. ZPP-a ovlašten od tuženika tražiti da mu stavi na raspolaganje sve informacije kojima tužitelj ne raspolaže.Tako, kada se zahtjev odnosi na neku opsežnu imovinu, može se od tuženika zahtijevati da dade njezin popis. U tužbi može biti nazančen i period na koji se odnosi zahtjev za davanje podataka o utajenoj ili prikrivenoj imovini, a ako nije naznačen, za to je mjerodavan trenutak zaključenja prethodnog postupka. ${ }^{28}$

\subsection{Zahtjev za davnje prisege i izjave o točnosti podataka}

Odredba čl. 186.b st. 1. ZPP-a formulirana je na način da tužitelju koji podnosi manifestacijsku tužbu stoje na raspolaganju još dva tužbena zahtjeva (traženja) i to na polaganje prisege i na davanje izjave da su položeni račun, predani pregled imovine i obveza te dani podaci o utajenoj ili prikrivenoj imovini potpuni i točni. Iz te odredbe može se zaključiti da tužitelj može zahtijevati davanje takve izjave i kada ne traži polaganje prisege od tuženika. Međutim, zakonodavac izričito ovlašćuje tužitelja da može zahtijevati od tuženika pod prisegom ispuniti zahtjev manifestacijske tužbe, ali i dati navedenu izjavu. Grbin opravdano upozorava da je takav tekst čl. 186.b st. 1. ZPP-a posljedica pogrešnog prevođenja čl. XLII. st. 1. austrijskog EGZOP-a. Ta odredba ovlašćuje podnositelja manifestacijske tužbe da od tužitelja zahtijeva položiti prisegu kako su njegovi navodi točni i potpuni. Prema tome, ta izjava o točnosti i potpunosti tuženikovih navoda nije po austrijskom pravu nikakva posebna činidba, već je njome jedino određen sadržaj prisege. Stoga bi takvo stajalište trebalo primijeniti i u hrvatskom pravu. Ovo zato što samostalni tužiteljev zahtjev u manifestacijskoj tužbi da se naloži tuženiku da izjavi kako su njegovi navodi točni i potpuni, koji bi se ostvarivao u ovršnom postupku, gubi svaki smisao. Opravdano se možemo zapitati je li razumno od nekoga očekivati izjavu kako je davao netočne podatke. Jer ako je svjesno govorio neistinu, on će bez daljnjega svejedno izjaviti da su njegovi podaci točni. Zbog toga valja temeljito sumnjati u pravnu učinkovitost i valjanost takve izjave. Zato bi tuženiku trebalo dopustiti, neovisno o postojanju odgovarajuće kondamnetorne presude, da svoju obvezu davanja izjave ispuni i dobrovoljno. Osim toga, nije jasno pred kim i u kojem bi obliku tuženik trebao dati svoju izjavu. Ako se tuženikova izjava promatra odvojeno od njegove eventualne prisege, postavlja se opravdano pitanje sadržaja same prisege i netko bi ga ponovno trebao izmisliti. ${ }^{29}$ Polaganje prisege u svezi s manifestacijskom tužbom u Austriji je uvedeno krajem 19. stoljeća, a u Republici

27 Tako je npr. neprihvatljivo da bi se putem takve tužbe moglo siliti odvjetnika kao punomoćnika tuženika da tužitelju otkrije podatke o utajenoj ili prikrivenoj imovini koje je saznao od svojeg klijenta. V. Grbin, ibid.

28 Tako i Dika, str. 12.

29 V. Grbin, str. 282 i 283. te pokušaj da se odredi sadržaj prisege u Dika, str. 12 i bilješku 15 , prema kojemu predloženi sadržaj prisege u cijelosti odgovara sadržaju izjave koju bi trebao dati tuženik i pokazuje da tuženikova prisega i izjava čine jednu cjelinu. Radi čega onda siliti tuženika koji je položio prisegu da dade i posebnu izjavu u kojoj će ponoviti sadržaj prisege? Zato traženje prisege više ima psihološki, nego pravni učinak. 
Hrvatskoj početkom 21. stoljeća u posve drukčijem pravnom ozračju od onoga koje je postojalo u Austriji. Pored toga, hrvatski zakonodavac ima izrazito odbojan stav prema prisezi tuženika. Doduše, mogućnost davanja prisege predviđena je kod saslušanja svjedoka, ali njega se ne može prisiliti da prisegne. Ako odbije prisegnuti, protiv njega se ne mogu primijeniti nikakve sankcije. ${ }^{30}$ Pored toga, prisegom iskaz svjedoka sam po sebi ne dobiva nikakvu veću dokaznu snagu. U postupku davanje lažnog iskaza svjedoka uz prisegu ili bez prisege kazneno je djelo prema odredbi čl. 305. st. 1. Kaznenog zakona (NN 125/11,144/12,56/15,61/15,101/17,118/18 - dalje KZ, koji je na snazi od 4. siječnja 2019.g.), ali za davanje lažnog iskaza svjedoka koji je pod prisegom nije propisana neka stroža kazna. Također je i lažni stranački iskaz kazneno djelo, ali samo ako je dan u postupku na temelju kojega je zasnovana konačna odluka suda. ${ }^{31}$ Iz toga je zaključiti da lažna prisega dana u smislu odredbe čl. 186.b st. 1. ZPP-a nije uopće kazneno djelo. ${ }^{32}$ Kada je tuženiku presudom naloženo davanje prisege, to se može ostvarivati u ovršnom postupku. Problem se javlja kada tuženik svoju obvezu davanja prisege želi ispuniti dobrovoljno. Prisega se u pravilu daje pred sudom, pa se postavlja pitanje je li nužno da se i kod dobrovoljnog davanja prisege tuženik pojavi pred sudom? Po jednom motrištu on to treba učiniti, a prisegu daje u izvanparničnom poistupku, dok je po drugome dopušteno dobrovoljno izvansudsko ispunjenje davanja prisege. Smatramo da je prihvatljivije ovo potonje rješenje, da tuženik svoju obvezu davanja prisege ispuni i bez sudjelovanja suda, ali u svezi s time javljaju se razna druga pitanja vezana uz način ispunjenja te obveze. Ipak bi bilo najbolje rješenje iz čl. 186.b st. 1. ZPP-a ukloniti odredbe o tuženikovoj prisezi i izjavi, jer se time tužiteljev pravni položaj u postupku i sporu ne bi pogoršao, već bi se oslobodio nepotrebnih neugodnosti, a sudovi suvišnog posla u vezi s primjenom tih odredbi.

\section{STUPNJEVITA TUŽBA U KOJOJ SU KUMULIRANA DVA I VIŠE TUŽBENIH ZAHTJEVA}

Tužitelj podnosi manifestacijsku tužbu sa svrhom da pribavi podatke koji su mu potrebni, da bi protiv tog ili tih tuženika mogao ostvariti zahtjev na neku drugu

30 Tako, prema odredbi čl. 270. ZPP-a, dokaz saslušanjem stranaka izvodi se bez davanja prisege. Mogućnost davanja prisege predviđena je u odredbama čl. 246. st. 1-3. ZPP-a prema kojemu sud može odlučiti da svjedok prisegne na iskaz koji je dao. Prisega se daje usmeno na zapisnik pred sudom izgovaranjem ovih riječi: "Prisežem čašću da sam o svemu što me je sud pitao istinu govorio i da ništa što sam o ovoj stvari znao nisam prešutio." Sud može odlučiti da svjedok prisegne i prije nego što bude saslušan.

31 Prema čl. 305. st. 1. KZ-a, svjedok, vještak, prevoditelj ili tumač koji u prethodnom kaznenom postupku, u postupku pred sudom, međunarodnim sudom (čiju nadležnost priznaje RH), arbitražnom postupku, u prekršajnom postupku, upravnom postupku, postupku pred javnim bilježnikom ili u stegovnom postupku dade lažni iskaz, nalaz ili mišljenje ili nešto lažno prevede - kaznit će se zatvorom od 6 mjeseci do 5 godina. Prema stavku 2. ovog članka, kaznom iz st. 1. istog članka kaznit će se i stranka u postupku (osim okrivljenika) koja dade lažni iskaz ako se na tom iskazu temelji konačna odluka u tom postupku.

32 Treba napomenuti da hrvatska pravna doktrina nije sklona prisezi kao parničnoj radnji. V. TrivaDika, str. 523. 
činidbu koja također proizlazi iz međusobnog pravnog odnosa stranaka. Tužitelj je uvjeren da takav zahtjev postoji, ali ga on bez manjkajućih podataka nije u stanju postaviti. Tek kada pribavi potrebne informacije i podatke, on bi u novoj parnici mogao ostvariti taj zahtjev, s obzirom na to da i takav drugi zahtjev mora biti preciziran. Razlozi ekonomičnosti naveli su austrijskog i našeg zakonodavca omogućiti tužitelju da istom tužbom pored manifestacijskog zahtjeva postavi i taj drugi još posve neodređeni zahtjev koji će precizirati naknadno, nakon što tuženik prvo udovolji zahtjevu iz manifestacijske tužbe. Takva tužba kojom se na specifičan način kumuliraju dva i više zahtjeva naziva se stupnjevitom tužbom. Tako npr. sud u Austriji najprije odlučuje međupresudom o manifestacijskom zahtjevu, a o drugom će zahtjevu odlučiti naknadno kada ga tužitelj bude precizirao. ${ }^{33}$ Nasuprot tome, odredba jednog kratkog stavka čl. XLII. st. 3. EGZPO-a kod nas je pretvorena u dva stavka čl. 186 b. st. 2. do 5. ZPP-a, koji su uvodno citirani te čl. 325.a ZPP-a. ${ }^{34}$ Pri tome je korišteno mnogo suvišnih riječi (izraza), zbog čega su ove odredbe nejasne ili pogrešno formulirane te podnositelja stupnjevite tužbe mogu odvratiti od njezine uporabe te namjeravane i korisne svrhe.

\subsection{Sadržaj tužbenih zahtjeva u stupnjevitoj tužbi}

Kako smo već spomenuli, u stupnjevitoj tužbi kumulirana su najmanje dva ili više zahtjeva. Prvo je tu manifestacijski zahtjev o kojemu sud treba prethodno pravomoćno odlučiti rješenjem i drugi zahtjev ili zahtjevi o kojima treba naknadno odlučiti. Ti zahtjevi, prema odredbama čl. 186. st. 2. i 3. ZPP-a, mogu biti različiti. To su, prema odredbi čl. 186.b st. 2. ZPP-a, manifestacijski zahtjev iz st. 1. istoga članka i to onaj koji se temelji na sadržaju već otprije postojećeg pravnog odnosa među strankama, koji se odnosi na polaganje računa ili onaj koji se odnosi na pregled imovine i obveza. Međutim, ako se tuženikove obveze prema tužitelju promatraju kao tužiteljeva imovina te ako pod tim razumijevamo samo tužiteljeve obveze o čemo je već prethodno bilo riječi, tada zahtjev za pregled tih obveza ne bi mogao biti predmetom stupnjevite tužbe jer se drugi zahtjev o kojem će sud naknadno

33 Dakle,odstupanje od pravila da tužbeni zhtjev mora biti određen već u tužbi je samo privremene naravi.

34 Prema čl.325 a st.1.ZPP,u povodu tužbi iz čl.186 b.st.1. i 2. ZPP sud će rješenjem prihvatiti zahtjev za polaganje računa, podnošenje pregleda imovine i obveza ili davanje podataka, ako utvrdi da je osnovan. Protiv toga rješenja tuženik može izjaviti žalbu u roku od osam dana koja ne odgađa ovrhu. Ako utvrdi da zahtjevi iz st. 1. ovog članka nisu osnovani, sud će donijeti rješenje iz čl. 186.b st. 4. ZPP-a protiv kojega nije dopuštena posebna žalba. Prema st. 3. ovog članka, nakon što tuženik položi račun, podnese pregled imovine i obveza ili se očituje o traženim podacima, odnosno nakon što utvrdi da je ovrha radi pribavljanja tih podataka ostala bez uspjeha ili da njezina provedba ili nastavak nisu svrhoviti, sud može na prijedlog tužitelja prije nego što donese rješenje iz čl. 186.b st. 4. ZPP-a odrediti vještačenje ili izvođenje drugih dokaza, ako ocijeni da je to potrebno radi provjere i dopune predloženog računa, podnesenog pregleda imovine i obveza ili danih podataka. Troškove izvođenja dokaza iz st. 3. ovog članka snosit će tuženik ako se pokaže da položeni račun, predani pregled imovine i obveza te dani podaci nisu točni i potpuni, odnosno ako odbije položiti račun, predati pregled imovine i obveza ili dati potrebne podatke. Napominje se da prema st. 5. istog članka tužitelj može u posebnoj parnici zatražiti naknadu štete koju je pretrpio zato što tuženik nije postupio u skladu s rješenjem iz st. 1. ovog članka. 
raspravljati ne može zasnivati na podacima o tužiteljevim obvezama. ${ }^{35}$ Što se tiče drugog, još nepreciziranog zahtjeva stupnjevite tužbe, ne bi se s njim mogao kumulirati i zahtjev za davanje podataka o utajenoj ili prikrivenoj imovini kojemu osnova postavljanja nije u nekom već postojećom pravnom odnosu stranaka, već mu temelj izričito proizlazi iz odredbe čl. 186.b st. 1. ZPP-a.

Prema odredbi čl. 186.b st. 3., pored mogućnosti postavljanja spomenutih manifestacijskih zahtjeva, prvi od zahtjeva postavljenih u stupnjevitoj tužbi u takvom slučaju može biti i zahtjev da sud tuženiku naloži tužitelju predati podatke koje mu tuženik ne želi dati, premda istima raspolaže, a koje mu je prema sadržaju građanskog pravnog odnosa dužan dati, odnosno koji se podaci mogu smatrati zajedničkim za obje stranke. ${ }^{36}$ Iz toga proizlazi da prvi od zahtjeva stupnjevite tužbe mora biti povezan s činjenicom da tužitelj ne može postaviti svoj drugi određeni zahtjev upravo zato što tuženik kršeći svoje obveze prema tužitelju to sprečava. Već smo naglasili da, prema odredbi čl. 186. st. 1. ZPP-a, tužba treba sadržavati određeni zahtjev u pogledu glavne stvari i sporednih traženja. Zato sadržaj prvog od zahtjeva stupnjevite tužbe mora biti u skladu s tom zakonskom odredbom. ${ }^{37}$ Predmet tog zahtjeva treba biti činidba i to neka od navedenih u čl. 186. st. 2. i 3. ZPP-a, a to su: isplata određenog iznosa novca, isporuka određene količine zamjenjivih stvari, predaja određenih stvari i prijenos određenih prava. Grbin opravdano postavlja pitanje čemu služi to nabrajanje mogućih činidbi, s obzirom na to da činidbe mogu biti vrlo različite, a sastoje se u davanju, činjenju, propuštanju ili trpljenju. ${ }^{38} \mathrm{U}$ stvarnosti gledano, kao rezultat prvog stadija postupka stupnjevite tužbe može slijediti tužiteljevo pravo na bilo koju od navedenih činidbi. Stoga navođenjem vrste činidbi koje mogu biti predmetom stupnjevite tužbe ograničava se tužitelja u njegovim materijalnim pravima. Pravna osobitost tog drugog tužbenog zahtjeva u tome je što u vrijeme podošenja stupnjevite tužbe on još nije konačno određen, jer u njemu nisu navedene visina novčane svote ni količina stvari, odnosno istovjetnost stvari ili prava koje tužitelj traži tužbom. Unatoč tome, taj se tužbeni zahtjev ne smatra nepotpunim, s obzirom na to da ZPP dopušta takav njegov sadržaj pozivom na svoje odredbe čl. 186. st. 2. i 3. Ipak, to odstupanje samo je privremenog karaktera jer će sud o tom tužbenom zahtjevu odlučiti tek kada isti bude preciziran. ${ }^{39}$

35 V. Grbin, str. 289.

36 O kojim se podacima tu radi, vidi pobliže u Dika, str. 22.

37 U protivnome, sud će s tužbom postupiti prema odredbi čl. 281. ZPP-a, koja propisuje da, kada sud utvrdi kako je tužba nerazumljiva ili nepotpuna ili kako postoje nedostaci koji se tiču sposobnosti tužitelja ili tuženika da budu stranke u parnici ili nedostaci u pogledu zakonskog zastupanja stranaka ili nedostaci koji se odnose na ovlaštenje zastupnika da pokrene parnicu kad je takvo ovlaštenje potrebno, sud će radi otklanjanja tih nedostatka poduzeti potrebne mjere predviđene ovim zakonom (čl. 83. i 109. ZPP-a).

38 V. Vediš-Klarić, str. 91. i dalje.

39 Prema odredbi čl. 241. ZOO-a, zastara se prekida podnošenjem tužbe i svakom drugom vjerovnikovom radnjom poduzetom protiv dužnika pred sudom ili drugim nadležnim tijelom radi utvrđivanja, osiguranja ili ostvarivanja tražbine. Ta materijalnopravna posljedica odnosi se i na drugi neprecizirani tužbeni zahtjev stupnjevite tužbe. Valja naglasiti da podnošenje samostalne manifestacijske tužbe ne rađa takvim posljedicama. V. Grbin, str. 290. 


\subsection{Postupak u povodu stupnjevite tužbe - prvi stadij}

Postupak u povodu stupnjevite tužbe odvija se u dva stadija. U prvome se raspravlja i odlučuje o manifestacijskom zahtjevu u smislu odredbe čl. 186.b st. 1. ZPP-a, a zatim, nakon što tužitelj pobliže odredi svoj sljedeći zahtjev, u smislu odredbi čl. 186.b st. 2. ili st. 3. ZPP-a o drugom zahtjevu. Kada sud odlučuje o prvom (tzv. manifestacijskom zahtjevu) od postavljenih zahtjeva treba razlikovati dvije situacije: kada utvrdi da je takav zahtjev utemeljen i kada utvrdi da nije. Tako, u smislu odrebe čl. 325.a st. 1. ZPP-a, sud će prihvatiti zahtjev za polaganje računa, podnošenja pregleda imovine i obveza ili davanje traženih podataka, ako utvrdi da je osnovan..$^{40}$ Zakonodavac nije objasnio razloge radi čega odluku o prihvaćanju ili neprihvaćanju tog zahtjeva donosi u obliku rješenja umjesto presude. U smislu odredbi čl. 129. ZPP-a, sud u pravilu o tužbenom zahtjevu odlučuje presudom, a iznimno rješenjem kao što je to u postupku zbog smetanja posjeda, u postupku izdavanja platnog naloga i odluke o parničnim troškovima. Trebalo bi razjasniti zbog čega se tim slučajevima pridružila i odluka o prvom od zahtjeva stupnjevite tužbe. Rješenje ne mora biti doneseno u kontradiktornom postupku. ${ }^{41} \mathrm{U}$ pogledu tog i takvog rješenja smatramo da ipak treba primijeniti odgovarajuće odredbe ZPP-a koje se odnose na presudu. Protiv rješenja iz čl. 325.a st. 1. ZPP-a tuženik može izjaviti žalbu, što je dvostranopravni lijek, ali je ujedno i nesuspenzivni jer ne odgađa ovrhu ${ }^{42} \mathrm{Kad}$ sud utvrdi da tužbeni zahtjev nije osnovan prema čl. 325.a st. 2. ZPP-a, donijet će rješenje iz čl. 186.b st. 4. ZPP-a, a to je rješenje kojim se tužitelju nalaže da u određenom roku precizira svoj drugi tužbeni zahtjev. Protiv tog rješenja nije dopuštena posebna žalba. Iz tako satkanih zakonskih odredbi izvodi se zaključak da sud, kad smatra da je prvi od zahtjeva stupnjevite tužbe neosnovan, ne donosi posebno rješenje o odbijanju tog zahtjeva, već na opisani način nastavlja postupak, a zatim odlučuje o tom zahtjevu i to presudom kojom ujedno odlučuje i o sada preciziranom drugom zahtjevu stupnjevite tužbe. ${ }^{43}$ Pri tome Grbin opravdano upozorava da takvo provođenje navedenih odredbi ZPP-a ne bi bilo u skladu s ciljem kojem teži stupnjevita tužba, a to je olakšanje tužiteljeva položaja. Naime, situacija tužitelja koji treba precizirati svoj drugi tužbeni zahtjev u slučaju kada je udovoljeno prvom njegovu zahtjevu povoljnija je od one u kojoj se nalazi kada je njegov prvi zahtjev odbijen ili kada se o njemu uopće nije odlučivalo. Stoga bi sud, kad ocijeni da prvi od tužbenih zahtjeva stupnjevite tužbe nije osnovan, trebao donijeti rješenje kojim se taj zahtjev odbija. Protiv tog rješenja tužitelju bi trebalo priznati pravo na

40 Grbin i Dika osnovano upozoravaju da je u čl. 325.a st. 1. ZPP-a očito došlo do redakcijske pogreške, jer iz njegova teksta slijedi da se on odnosi na tužbe iz čl. 186.b st. 1. i 2. ZPP-a, ali njegov sadržaj upućuje na to da se on zapravo odnosi na tužbe iz čl. 186. st. 2. i 3. ZPP-a. V. Dika, str. 9. i 22 te Grbin str. 291.

41 Tako bi bilo moguće donositi rješenja na temelju priznanja, zbog ogluhe, zbog izostanka i bez održavanja rasprave, a zakonodavac je ipak odredio da se te i takve odluke donose u obliku presude. Grbin, ibid.

${ }^{42}$ Prema čl. 381. ZPP-a, u postupku po žalbi protiv rješenja na odgovarajući način će se primjenjivati odredbe koje važe za žalbu protiv presude. Odredbe o odgovoru na žalbu primjenjivat će se samo na žalbe izjavljene protiv rješenja kojima je postupak pred prvostupanjskim sudom okončan.

43 V. Dika, str. 19. 
samostalnu žalbu za koju bi rok uz odgovarajuću primjenu čl. 325.a st. 1. ZPP-a iznosio osam dana te mu na taj način pružiti priliku da za sebe postigne povoljniju odluku o prvom postvaljenom tužbenom zahtjevu. Tek nakon pravomoćnog okončanja tog žalbenog postupka, sud bi trebao postupiti u smislu odredbe čl. 325.a st. 2. ZPP-a. U protivnomu, kakva bi inače smisla imalo odlučivanje o prvom postavljenom tužbenom zahtjevu nakon što je tužitelj već precizirao drugi tužbeni zahtjev i kakve bi posljedice nastale kad bi prvostupanjski ili drugostupanjski sud naknadno presudom prihvatio prvi od tužbenih zahtjeva stupnjevite tužbe? Nije svrha vođenja postupka povodom prvog postavljenog tužbenog zahtjeva u tome da tužitelj ishodi donošenje za njega povoljne sudske odluke, nego u tome da pribavi podatke koji su tužitelju potrebni radi postavljanja drugog određenog tužbenog zahtjeva. Stoga rješenje kojim je udovoljeno prvom zahtjevu stupnjevite tužbe iz odredbe čl. 325.a st. 1. ZPP-a nije dovoljno za preciziranje drugog tužbenog zahtjeva. Da bi tužitelj to mogao učiniti, potrebno je da tuženik postupi u skladu s rješenjem suda, a to znači položi račun, preda pregled imovine i obveza, odnosno dade potrebne podatke. To tuženik može učiniti dobrovoljno u paricijskom roku, a nakon toga tužitelj može tu svoju tražbinu ostvariti u ovršnom postupku primjenom odredbi čl. 247., 248. i 262. Ovršnog zakona (NN 112/12,25/13,94/14 i 55/16,73/17 - dalje OZ). ${ }^{44}$ Tako, prema odredbi čl. 247. st. 5. OZ-a, pravo na sudske penale prestaje od dana podnošenja prijedloga za ovrhu iz st. 4. ovoga članka, a plaćanje sudskih penala može se tražiti sve dok se na temelju ovršne isprave ne predloži ovrha radi ostvarivanja nenovčane tražbine. Ako ovrha bude obustavljena, ponovno oživljava pravo ovrhovoditelja na sudske penale. Kod ovrhe prema solidarnim dužnicima, po odredbi čl. 207. st. 1., ako na temelju ovršne isprave dva ili više ovršenika solidarno odgovaraju, sud koji je nadležan za bilo kojeg od solidarnih ovršenika donijet će

44 Prema odredbama čl. 247. st. 1. OZ-a, kada dužnik ne ispuni u roku neku svoju nenovčanu obvezu na činjenje, trpljenje ili nečinjenje, utvrđenu pravomoćnom sudskom odlukom, sudskom nagodbom ili javnobilježničkom ispravom, sud će u ovršnom postupku na prijedlog vjerovnika kao ovrhovoditelja odrediti dužniku kao ovršeniku naknadni primjereni rok i izreći da će ovršenik, ako ne ispuni svoju obvezu u tom roku, biti dužan isplatiti ovrhovoditelju određeni iznos novca za svaki dan zakašnjenja ili koju drugu jedinicu vremena (sudski penali), počevši od isteka tog roka. Prema st. 2. ovog članka, naknadno određeni primjereni rok iz st. 1. počinje teći od dostave ovršeniku prvostupanjskog rješenja kojim je taj rok određen. Žalba ne utječe na tijek toga roka. Prema st. 3. istoga članka, ako ovršenik najkasnije u roku od petnaest dana nakon pravomoćnosti rješenja iz st. 1. ispuni svoju obvezu, sud može u istom ovršnom postupku na zahtjev ovršenika koji je podnesen u roku od osam dana od ispunjenja obveze smanjiti iznos dosuđenih penala, vodeći pri tome računa o svrsi zbog koje je naredio njihovo plaćanje. Podnošenje tog zahtjeva bez utjecaja je na određivanje i provedbu ovrhe na temelju pravomoćnog rješenja o plaćanju sudskih penala iz st. 1. ovog članka. Prema st. 4. istoga članka, plaćanje sudskih penala može se tražiti sve dok se na temelju ovršne isprave ne predloži ovrha radi ostvarivanja nenovčane tražbine. Prema st. 6. ovog članka, pravo na sudske penale prestaje od dana podnošenja prijedloga za ovrhu iz st. 4. Prisilna naplata sudskih penala dospjelih do toga dana može se tražiti u smislu odredaba čl. 204. ovog Zakona. Prema st. 6. ovog članka, ako ovrha iz st. 5. ovog članka bude obustavljena, pravo ovrhovoditelja na sudske penale oživljava. I konačno, prema st.7. ovog članka, ako je protekao rok u kojem se po Zakonu može tražiti ovrha, ne može se tražiti izricanje sudskih penala. Ako je prijedlog za izricanje sudskih penala podnesen u zakonskom roku, obveza plaćanja sudskih penala postoji sve dok ovršenik ne izvrši dužnu činidbu. Prema odredbi čl. 248. OZ-a, na temelju pravomoćnog rješenja o plaćanju sudskih penala iz čl. 247. ovog Zakona, sud će u istom ovršnom postupku u kojem je donio to rješenje na prijedlog vjerovnika kao ovrhovoditelja donijeti i rješenje o ovrsi radi prisilne naplate dosuđenih penala. 
Dr. sc. Mladen Pavlović: Manifestacijska stupnjevita tužba i tužba vjerovnika prije dospjelosti njegove... Zbornik radova Pravnog fakulteta u Splitu, god. 56, 4/2019, str. 923-944

protiv svih njih ili samo nekih od njih, u skladu s ovrhovoditeljevim prijedlogom, jedno rješenje o ovrsi. ${ }^{45}$

\subsection{Postupak u povodu stupnjevite tužbe - drugi stadij}

Nakon toga tužitelj bi trebao tražiti nastavak postupka i postaviti drugi određeni tužbeni zahtjev za koji vrijede uobičajena pravila parničnog postupka. Međutim, u odredbama čl. 186.b st. 2. i 3. u svezi sa čl. 325.a st. 3. i 4., predviđena je mogućnost da se između donošenja usvojene odluke po prvom od zahtjeva stupnjevite tužbe i njezina drugog preciziranog tužbenog zahtjeva vodi još jedan postupak $s$ još neutvrđenim pravnim učincima na samu stupnjevitu tužbu. ${ }^{46}$ Ovo zato što sud, kad utvrdi da je ovrha radi ostvarenja tužiteljeve tražbine ostala bezuspješna ili da daljnja njezina provedba ili nastavak nisu svrhoviti, može po tužiteljevom prijedlogu, prije nego što donese rješenje iz čl. 186.b st. 4. ZPP-a, odrediti izvođenje dokaza vještačenjem ili drugih dokaza ako ocijeni da je to potrebno radi provjere i dopune položenog računa, podnesenog pregleda imovine i obveza, odnosno ako tuženik uskrati ispunjenje tih svojih obveza. ZPP ne propisuje da sud u svezi s izvođenjem tih dokaza donosi kakve odluke, tako da se može smatrati da rezultati tog dokazivanja trebaju biti tužitelju stavljeni izravno na raspolaganje kako bi mu se olakšalo preciziranje drugog tužbenog zahtjeva. U svezi s tim postavlja se pitanje

44 Prema odredbama čl. 262. OZ-a, ako radnju utvrđenu u ovršnoj ispravi može obaviti samo ovršenik, sud će rješenjem o ovrsi odrediti ovršeniku primjereni rok za ispunjenje obveze (st. 1.). Rješenjem o ovrsi sud će istovremeno zaprijetiti ovršeniku da će protiv njega izreći određenu novčanu kaznu u skladu s odredbama čl. 16. OZ-a ako u roku koji mu je određen ne ispuni obvezu (st. 2.). Ako ovršenik u roku koji mu je određen ne ispuni obvezu, sud će na prijedlog ovrhovoditelja rješenjem ovršeniku izreći novčanu kaznu kojom mu je zaprijetio. U tom rješenju sud će ovršeniku odrediti novi rok za ispunjenje obveze i zaprijetiti novom novčanom kaznom u većem iznosu nego što je bila ona kojom je prije zaprijetio, ako ni u tom roku ne ispuni obvezu (st. 3.). Pri odmjeravanju visine novčane kazne u propisanim granicama, sud će voditi računa o značenju radnje koju je ovršenik dužan obaviti te o drugim okolnostima slučaja (st. 4.). Ovršenik koji je ispunio svoju obvezu u roku koji mu je sud odredio, dužan je bez odgode o tome obavijestiti sud i priložiti nesumnjive dokaze o tome. Nesumnjivim dokazom smatrat će se ovjerovljena pisana izjava ovrhovoditelja o tome da je radnja obavljena, javnobilježnički zapisnik ili zapisnik sudskog ovršitelja o obavljanju radnje, nalaz i mišljenje sudskog vještaka da je radnja obvaljena, predaja djela koje je radnjom učinjeno u sudski ili javnobilježnički polog i sl. U protivnome, smatrat će se da radnja nije obvaljena (st. 5). Prije izricanja novčane kazne sud će omogućiti ovršeniku da se očituje, a po potrebi održat će i ročište radi izvođenja dokaza (st. 6). Ako radnja koju može obaviti samo ovršenik ne ovisi iskljčivo o njegovoj volji (npr. stavaranje određenog umjetničkog djela, specijalnog proizvoda i sl., ovrhovoditelj nema pravo tražiti ovrhu iz st. 1. ovog članka, već samo naknadu štete.

45 Tako je pravomoćnim rješenjem Trgovačkog suda u Splitu IV P-477/2010 od 30. rujna 2010. god. naloženo šestorici tuženika da u roku od 8 dana i pod prijetnjom ovrhe dostave tužitelju financijsko izvješće o poslovanju, poslovne knjige, knjigu dionica tuženika pod 1. kao i da pod prisegom polože račun i predaju potpuni pregled imovine i obveza tuženika pod 1. i to za period od 1. I. 1999. do udovoljenja zahtjevu. Kako nijedan od tuženika nije postupio po pravomoćnom Rješenju prvostupanjskog suda, uslijedio je prijedlog ovrhovoditelja od 11. svibnja 2017. god. radi izricanja sudskih penala kojem je prijedlogu Općinski sud u Splitu udovoljio svojim Rješenjem br. Ovr-2032/17 od 16. svibnja 2017. god. te je odredio da su, ukoliko ne ispune svoju obvezu iz Rješenja Trgovačkog suda Split u određenom roku, dužni solidarno isplatiti ovrhovoditelju iznos od $1.000,00 \mathrm{kn}$ za svaki dan kašnjenja. Dva su pitanja u vezi $\mathrm{s}$ tim do kada se penali najduže mogu izricati i što je s provođenjem ovrhe.

46 O mogućem scenariju tog postupka v. Dika, str. 20. 
troškova izvođenja dokaza, koje je riješeno odredbom čl. 325.a st. 4. ZPP-a. ${ }^{47}$ Pored toga, tužitelj može u posebnoj parnici zatražiti od tuženika naknadu štete koju je pretrpio zbog toga što tuženik nije postupio u skladu s rješenjem kojim je prihvaćen prvi od zahtjeva stupnjevite tužbe. Dakle, tek nakon eventualnog izvođenja navedenih dokaza po prijedlogu tužitelja, sud će donijeti rješenje iz odredbe čl. 325.a st. 4. ZPP-a, tj. pozvat će tužitelja da u određenom roku precizno postavi svoj drugi tužbeni zahtjev. Ukoliko pak sud odbije prvi od zahtjeva stupnjevite tužbe, neće doći u obzir izvođenje navedenih dokaza te će odmah donijeti rješenje iz odredbe čl. 186. st. 4. ZPP-a. Ako tužitelj suglasno sa sudskim rješenjem precizira drugi tužbeni zahtjev stupnjevite tužbe, daljni postupak provodi se kao u povodu svake druge kondamnetorne tužbe. U slučaju da tužitelj tako ne postupi, rješenje iz odredbe čl. 186. st. 4. ZPP-a treba smatrati rješenjem kojim se u smislu odredbi čl. 109. ZPP-a poziva tužitelja da tužbu dopuni, pa ovisno o daljnjem tužiteljevu ponašanju, stupnjevitu tužbu u pogledu drugog tužbenog zahtjeva treba odbaciti, odnosno smatrati da je tužba u tom dijelu povučena. ${ }^{48}$ Kako u vrijeme podnošenja stupnjevite tužbe njezin drugi tužbeni zahtjev nije preciziran, kada ga tužitelj konačno odredi može se pokazati da treba ponovno nazanačiti vrijednost predmeta spora. Ako taj drugi tužbeni zahtjev glasi na novčani iznos, tužitelj to ne treba učiniti jer upravo naznačena svota predstavlja vrijednost predmeta spora po ovom drugom tužbenom zahtjevu. U drugim slučajevima, kad se drugi precizirani tužbeni zahtjev ne odnosi na novčani iznos, tužitelj treba naznačiti vrijednost predmeta spora sukladno odredbama čl. 40. st. 2. ZPP-a ${ }^{49}$ Pri tome izgleda da su u odredbu čl. 186. st. 5. ZPP-a koja nalaže tužitelju da ponovno naznači vrijednost predmeta spora zalutale odredbe čl. 35.-37. i 39. ZPP-a koje se uopće ne odnose na naznačivanje, već na izračunavanje vrijednosti predmeta spora. ${ }^{50}$ Navedeno ukazuje, ako i ubuduće

47 Prema odredbi čl. 325a. st. 4. ZPP-a, troškove izvođenja dokaza iz st. 3. ovog članka snosit će tuženik, ako se pokaže da položeni račun, predani pregled imovine i obveza te dani podaci nisu bili točni ni potpuni, odnosno ako odbije položiti račun, predati pregled imovine i obveza ili dati potrebne podatke.

48 V. Dika, str. 21.

49 Vidi bilješku br. 19 ovog napisa.

50 Prema odredbama čl. 35. ZPP-a, kada je za utvrđivanje stvarne nadležnosti, sastava suda, prava na izjavljivanje revizije i u drugim slučajevima predviđenima u ovom Zakonu mjerodavna vrijednost predmeta spora, uzima se u obzir samo vrijednost glavnog zahtjeva (st. 1.). Kamata, parnični troškovi, ugovorna kazna i ostala sporedna potraživanja ne uzimaju se u obzir ako ne čine glavni zahtjev (st. 2.).

Prema odredbi čl. 36. ZPP-a, ako se zahtjev odnosi na buduća davanja koja se ponavljaju, vrijednost predmeta spora računa se po njihovu zbroju, ali najviše do iznosa koji odgovara zbroju davanja za vrijeme od pet godina.

Prema odredbama čl. 37. ZPP-a, ako jedna tužba protiv istog tuženika obuhvaća više zahtjeva koji se temelje na istoj činjeničnoj i pravnoj osnovi, vrijednost predmeta spora određuje se prema zbroju vrijednosti svih zahtjeva (st. 1.) (pri tome uvjeti istovjetnosti činjenične i pravne osnove moraju biti kumulativno ispunjeni, op. a.). Ako zahtjevi u tužbi proizlaze iz raznih odnosa (različite činjenične $\mathrm{i}$ pravne osnove, op. a.) ili pojedine zahtjeve ističu različiti tužitelji ili su pojedini zahtjevi istaknuti protiv različitih tuženika, vrijednost predmeta spora određuje se prema vrijednosti svakog pojedinog zahtjeva (st. 2.).

Prema odredbi čl. 39. ZPP-a, ako se tužbom zahtijeva samo davanje osiguranja za stanovito potraživanje ili ustanovljenje založnog prava, vrijednost predmeta spora određuje se prema iznosu potraživanja koje treba osigurati. Ali ako predmet zaloga ima manju vrijednost od potraživanja koja treba osigurati, kao vrijednost predmeta spora uzet će se vrijednost predmeta zaloga. 
sve ostane na statusu quo, da pred sud i stranke ostaje mukotrpan put u postupku povodom stupnjevite tužbe, čije je uvođenje trebalo doprinijeti ostvarenju načela ekonomičnosti i koncentracije postupka. ${ }^{51}$

\section{TUŽBA VJEROVNIKA NA ISPUNJENJE PRIJE DOSPJELOSTI NJEGOVE TRAŽBINE}

Prema odredbi čl. 326. st. 1.ZPP-a, sud može naložiti tuženiku da izvrši određenu činidbu samo ako je ona dospjela do zaključenja glavne rasprave. Pri tome dopušta dvije iznimke i to: a) ako sud prihvati zahtjev za uzdržavanje, može obvezati tuženika i na činidbe koje nisu dospjele te b) donijeti presudu kojom se tuženik obvezuje da preda ili preuzme stvari dane u najam ili zakup i prije prestanka tih odnosa. U slučaju da sud utvrdi da utužena tražbina do zaključenja glavne rasprave nije dospjela, on će, prema stajalištu dosadašnje sudske prakse, donijeti presudu kojom će odbiti tužbeni zahtjev. ${ }^{52}$ Prvomoćnost takve presude neće predstavljati zapreku vođenju ponovne parnice među istim strankama o istom tužbenom zahtjevu nakon dospijeća tužiteljeve tražbine. Postoji i mogućnost da tužitelj prije dospijeća njegove tražbine, suglasno odredbama čl. 187. ZPP-a, zatraži deklaratornu zaštitu koja bi mu omogućila utvrđenje postojanja tražbine, ali ne i ostvarivanje njegova prava na njezino ispunjenje, jer bi radi ispunjenja tražbine morao podnijeti novu tužbu tek kada tražbina dospije. ${ }^{53}$ Predmetom odredbi čl. 186.c ZPP-a jest pitanje može li sud prije nego što je činidba dospjela naložiti tuženiku da je o dospjelosti ispuni? To nema nikakve veze s materijalnim pravom, jer i kad sud donese svoju odluku prije dospijeća tužiteljeve tražbine, to ne utječe na njegovu dužnost da je ispuni tek po njezinu dospijeću. Kada sud donosi presudu kojom nalaže ispunjenje još nedospjele tražbine, mora prethodno ocijeniti hoće li se u budućnosti ostvariti određene okolnosti koje u vrijeme zaključenja glavne rasprave još nisu postojale. Sud se, dakle, mora upustiti u predviđanja koja su nesigurna i za sud nisu preporučljiva. ${ }^{54}$ Ipak, da bi se olakšao vjerovnikov položaj i omogućilo mu se brže i s manje troškova ostvariti kondamnetornu zaštitu, uvedene su još Novelom ZPP /2003 odredbe čl. 186.c. Zajednička je odredba tog članka da, za razliku od odredbi čl. 326. st. 2. i 3. ZPP-a, daje vjerovniku pravo od suda tužbom tražiti kondamnetornu zaštitu, neovisno o tome o kojoj je vrsti tražbine riječ, s tim da je to pravo uvjetovano postojanjem određenih pretpostavki, a ne proizlazi iz samih zakonskih odredbi, kako bi se to moglo očekivati.

51 V. Grbin, str. 292.-294.

52 V. odluke VSRH-a, Rev-555/95 od 14. I. 1999. IO 1/99-37 i Rev-3068/98 od 2. II. 1999. - IO 2/99-158

53 O tome više: Mladen Pavlović, "Pravne osobitosti tužbe na utvrđenje i konstitutivne tužbe", PuG, Zagreb, br. 4/18. Kada je neka činidba dospjela i kada vjerovnik može tražiti njezino ispunjenje te kada ju je dužnik dužan ispuniti, to su pitanja materijalnopravne naravi koja reguliraju odredbe čl. 173.-177. ZOO-a, a time se ne bavi ni čl. 326. ZPP-a.

54 Triva-Dika, str. 405. i 584. 


\subsection{Pretpostavke za pružanje pravne zaštite prema oredbama čl. 186.c ZPP-a}

Tužitelj može od suda zatražiti da tuženiku naloži da mu ispuni dužnu činidbu u vrijeme njezine dospjelosti, ako su pri tome ispunjene sljedeće pretpostavke: a) mora postojati vjerojatnost tužiteljeve tražbine, b) tražbina ne smije biti dospjela, c) vrijeme dospjelosti tražbine mora biti poznato i naznačeno u tužbenom zahtjevu i d) tužitelj mora učiniti vjerojatnim postojanje pravnog interesa za utuženje svoje tražbine prije njezina dospijeća. Prema tome, u vrijeme podnošenja tužbe tužiteljeva tražbina mora već postojati, jer se ne može utužiti buduća i neodređena tražbina. Utužiti se može bilo koja tražbina, neovisno o vrsti pravnog odnosa iz kojeg proistječe i o sadržaju dužne činidbe. ${ }^{55}$ Tražbina ne smije dospjeti ni prije zaključenja glavne rasprave, čega tužitelj treba biti svjestan, pa unatoč tome zatražiti kondamnetornu zaštitu. Ako je tužiteljeva tražbina već dospjela, na nju se ne primjenjuju odredbe čl. 186.c ZPP-a. Također, ako tužitelj smatra da je njegova tražbina dospjela, a sud utvrdi protivno, tužbeni će zahtjev biti odbijen jer se nisu ispunile pretpostavke materijalnog prava o njenom dospijeću. Odredbe čl. 186.c ZPP-a primjenjuju se samo onda kada tužitelj smatra kako ima pravni interes od suda zahtijevati da se o njegovoj tražbini odluči prije njezina dospijeća.

Prema čl. 186.c ZPP-a, dopušteno je tužitelju svoju tražbinu utužiti prije dospjelosti, ali ne i zahtijevati od suda da naloži tuženiku svoju obvezu ispuniti prije njezine dospjelosti sukladno odredbama materijalnog prava. ${ }^{56}$ Dakle, sud može odlučiti o tužbenom zahtjevu prije njegove dospjelosti, ali ne može naložiti tuženiku ispunjenje tražbine prije njezine dospjelosti. Ako sud utvrdi drugo vrijeme dospjelosti tražbine od onog koje je naznačio tužitelj, neće odbiti tužbeni zahtjev, već će naložiti tuženiku da svoju obvezu ispuni u vrijeme koje je sud utvrdio kao vrijeme dospijeća tražbine, pod pretpostavkom da prema utvrđenju suda ta tražbina nije dospjela prije vremena naznačenog u tužbi. Ovlaštenje tužitelja na podnošenje tužbe iz čl. 186.c ZPP-a bitno je ograničeno potrebom da je tužitelj dužan učiniti vjerojatnim postojanje svojeg pravnog interesa za podizanje te tužbe. Zakonodavac primjerice navodi slučajeve u kojima tužitelj ima takav pravni interes: kad tuženik ozbiljno dovodi u pitanje postojanje svoje još uvijek nedospjele tražbine ili će je morati sudskim putem ostvarivati nakon što ona dospije ili pak iz drugih razloga koji opravdano ukazuju na postojanje tužiteljeva pravnog interesa. Ako sud ocijeni da tužitelj nema pravni interes tražiti donošenje presude prema odredbama čl. 186.c

55 Tu se ne radi o tražbinama iz čl. 326. st. 2. i 3. ZPP-a, za koje vrijedi povoljniji režim od onog iz odredbi čl. 186.c ZPP-a.

56 Tako, primjerice, prema odredbama čl. 173. ZOO-a, dužnik je dužan ispuniti obvezu u roku koji je predviđen ugovorom (st. 1.). Ako rok ispunjenja nije predviđen ugovorom, dužnik je dužan ispuniti obvezu u roku koji je predviđen zakonom (st. 2.). Ako rok nije određen ni ugovorom, ni zakonom, a cilj posla, narav obveze i ostale okolnosti ne zahtijevaju stanoviti rok za ispunjenje, vjerovnik može zahtijevati odmah ispunjenje obveze, a dužnik sa svoje strane može zahtijevati od vjerovnika da odmah primi ispunjenje (st. 3.). Prema čl. 183. ZOO-a, dužnik dolazi u zakašnjenje kad ne ispuni obvezu u roku određenom za ispunjenje (st. 1.). Ako rok za ispunjenje nije određen, dužnik dolazi u zakašnjenje kada ga vjerovnik pozove da ispuni obvezu, usmeno ili pisanim putem, izvansudskom opomenom ili započinjanjem nekog postupka čiji je cilj da se postigne ispunjenje obveze (st. 2.). 
ZPP-a, neće se upuštati u daljnju ocjenu o postojanju nedospjele tužiteljeve tražbine, već će tužbu odbaciti. Dakle, pravni interes se pojavljuje kao procesna pretpostavka o kojoj ovisi daljnje vođenje parničnog postupka. Kako je ocjena suda da će neka tražbina tek u budućnosti dospjeti vrlo rizična i nesigurna, jer se ne temelji na utvrđenjima suda nego samo na njegovu predviđanju, primjena odredbe čl. 186.c st. 1. ZPP-a treba biti iznimka od pravila iz čl. 326. st. 1. ZPP-a koje propisuje da sud može naložiti tuženiku izvršenje određene činidbe samo ako je ona dospjela do zaključenja glavne rasprave. To ovisi i o sudskoj praksi - ako bi ona velikodušno prihvaćala tvrdnje tužitelja o postajanju njihova pravnog interesa, iznimka se lako može pretvoriti u pravilo. Time bi se širom otvorila vrata pružanju kondamnetorne zaštite vjerovnicima čije tražbine nisu dospjele, a to ne bi bilo dobro, niti je to ratio odredbi čl. 186.c ZPP-a. ${ }^{57}$

\subsection{Ovrha presude kojom je odlučeno o nedospjeloj tražbini}

Kako smo već spomenuli, tužba iz čl. 186.c ZPP-a omogućava donošenje kondamnetorne presude prije dospjelosti utužene novčane ili nenovčane tražbine kojom se nalaže tuženiku da svoju obvezu ispuni tek kada ona dospije. Ovdje se tužiteljeva ušteda na vremenu sastoji u tome da će on u vrijeme dospjelosti svoje tražbine već raspolagati odgovarajućom ovršnom ispravom. Time će prištedjeti trud ishođenja takve isprave tek po njezinoj pravomoćnosti. Međutim, ipak neće moći tražiti namirenje svoje tražbine prije nego ona dospije na realizaciju. Dakle, morat će pričekati njezinu dospjelost koja je utvrđena pravomoćnom presudom, pa tek onda, ako tuženik ne ispuni dobrovoljno svoju obvezu u paricijskom roku, nakon što sud utvrdi ovršnost presude, tražbinu ce moći prisilno realizirati.

\section{ZAKLJUČNA RAZMATRANJA}

Ratio stupnjevite tužbe ogleda se u činjenici da su u praksi česti slučajevi u kojima tužitelj jednostavno nije u mogućnosti postaviti određeni tužbeni zahtjev zato što mu tuženik ne želi položiti račun ili dati pregled neke imovine i obveza u skladu s odredbama materijalnog prava ili ugovora koji se primjenjuju na njihov međusobni pravni odnos ili zato što mu tuženik ne želi dati potrebne podatke o utajenoj ili prikrivenoj imovini, a vjerojatno je da o toj imovini nešto zna. Do takvih situacija često dolazi u odnosima između trgovačkih društava i njihovih članova, između nalogodavca i nalogoprimca, između autora i nakladnika, između poslodavca i radnika, prilikom podjele bračne stečevine itd. Naziv stupnjevita tužba uveden je zbog toga što se željelo učinkovito omogućiti ostvarenje prava na polaganje računa ili davanja pregleda neke imovine i obveza, a posljedično nakon toga i na ostvarenje tražbine u parničnom postupku suglasno odredbama čl. 186.b i 326.a ZPP-a. Pri tome je postupak po stupnjevitoj tužbi podijeljen u dva stadija.

57 Grbin, str. 295-297. 
Tijekom prvog stadija tuženiku se nalaže polaganje računa ili davanja pregleda neke imovine i obveza te priopćenje što mu je poznato o utajenoj ili prikrivenoj imovini, s tim da sve to može učiniti pod prisegom ili bez prisege i davanjem izjave kako su položeni račun, predani pregled imovine i obveza, odnosno dani podaci o utajenoj ili prikrivenoj imovini potpuni i točni. Tijekom drugog stadija postupka raspravlja se u povodu određenog tužbenog zahtjeva koji je tužitelj dužan postaviti nakon okončanja prvog stadija u sudski određenom roku. Prema tome, stupnjevita tužba uvedena je kao iznimka od pravila da tužbeni zahtjev mora biti određeno postavljen već u tužbi suglasno odredbama čl. 186. st. 1. ZPP-a. U stupnjevitoj tužbi se, pored tzv. manifestacijskog zahtjeva koji u startu mora biti određeno postavljen, ističe i nespecificirani kondamnetorni zahtjev koji je tužitelj dužan kvalitativno i kvantitativno odrediti tek nakon što budu ispunjene potrebne pretpostavke za njegovo određenje. Ne postoje neka opća pravila koja propisuju kako su druge (treće) osobe dužne učiniti dostupnima podatke koji su potrebni tužitelju. Ta dužnost postoji samo kao iznimka koja je uspostavljena manifestacijskom tužbom za osobe za koje je vjerojatno da nešto znaju o utajenoj ili prikrivenoj imovini. U ostalim slučajevima dužnost davanja podataka može samo proizlaziti iz pozitivnih zakonskih propisa ili sklopljenog ugovora međe strankama. Tužitelj za podnošenje manifestacijske tužbe mora imati imovinskopravni interes i istu upravo podnosi sa svrhom da pribavi potrebne podatke kako bi protiv tog istog tuženika mogao ostvariti zahtjev na neku drugu pripadajuću činidbu koja također proizlazi iz sadržaja njihova međusobnog pravnog odnosa. Razlozi ekonomičnosti i koncentracije postupka zakonodavca su naveli da omogući tužitelju istom tužbom pored manifestacijskog zahtjeva postaviti i drugi posve nespecificirani zahtjev koji će konačno opredijeliti nakon što tuženik udovolji prvom zahtjevu u smislu odredbe čl. 186.b st. 1. ZPP-a. Stupnjevita tužba trebala je olakšati poziciju tužitelja u parnicama radi ostvarivanja prava sukladno odredbama čl. 186.b st. 2. i 3. ZPP-a. Međutim, razmatrajući pomno odredbe čl. 186.b ZPP-a, u ovome radu došli smo do istih spoznaja do kojih su prije više od desetak godina došli naši eminentni autori građanskog parničnog procesnog prava koje smo naveli i često citirali te možemo ponovno konstatirati da stupnjevita tužba nije postigla svoj cilj ni svrhu kojoj je bila namijenjena. Posebno je začuđujuće da ni u skoroj budućnosti nema nagovještaja o korigiranju nepotrebno glomaznih i složenih odredbi sukladno iznesenim primjedbama na koje je u tekstu ovog napisa pojedinačno ukazano. To pokazuje da se ne prate pozitivna zapažanja u ovoj procesnoj materiji.

Povodom tužbe vjerovnika na ispunjenje njegove tražbine prije dospjelosti treba iznimno omogućiti zaštitu njegovih prava kao tužitelja kad tuženik svojim ponašanjem obezvređuje tužitelja i ozbiljno dovodi u pitanje postojajanje njegove tražbine koja još nije dospjela, a posebno kad pokazuje svojim postupcima da će tu tražbinu tužitelj morati ostvarivati prisilno putem suda ili iz drugih posebno važnih razloga za koje ima pravni interes da se udovolji takvom zahtjevu tužitelja. Sud je pri tome dužan ispitati jesu li ispunjene tražene propisane zakonske pretpostavke. Premda je ova tužba predviđena kao iznimka, pozivom na odedbu čl. 326. st. 1. ZPP-a, s obzirom na česte pojave u praksi neispunjenja preuzetih obveza u roku, 
pa ni nakon pravomoćno okončanog sudskog postupka, ona bi lako mogla postati pravilo.

\section{THE MANIFESTATION OF THE DIFFERENT STAGES OF LEGAL ACTION AND THE LEGAL ACTION OF CREDITORS BEFORE MATURITY OF THEIR MONETARY CLAIMS}

The legal characteristics of the manifestation of the stages of legal action and what was to be achieved by them are considered in this paper. Legal action in particular which is put to the courts is analysed together with the procedure which is implemented in two phases. Certain important issues are herewith pointed out which arise when dealing with ownership interests in taking this legal action. An overview of the ownership and obligations and especially details on understated and concealed property is provided. There is a plea for the provision to be repealed for making a sworn statement on the accuracy of given data and justifiable reasons for such a change. It is emphasised, that acts which oblige the defendant from mutual party relations, the Civil Procedure Act (CPA) (ZPP) does not need to limit according to type because this without reason limits the rights of the claimant as creditor. The reasons for reformulating the provisions of art.186.b section 2 and 3 of CPA (ZPP) of the different stages of legal action are mentioned as are other observations to which the legislator has not reacted in the last ten or more years since the existing provisions from art.186 b of CPA (ZPP) in their application. Furthermore, there are no indications that this will happen in the near future. It is because of this that these legal actions achieve with great difficulty the aim and purpose for which they were intended. In opposition to this, the creditor's lawsuit to gain monetary claims before their maturity, which in our country's legal action process system is noted as an exception, could easily, given the common behaviour of the debtor in defaulting on meeting their assumed obligations, in the current economic conditions become the rule.

Key words: manifestation of legal action by stages, ownership interests, creditor's legal action to fulfil monetary claims before maturity 